\title{
PANGAN SETENGAH JADI BERBASIS IKAN SEBAGAI SALAH SATU ALTERNATIF PENURUNAN ANGKA STUNTING DAN PENINGKATAN ANGKA KECUKUPAN PROTEIN (AKP) TINGKAT RUMAH TANGGA
}

\author{
Oke Anandika Lestari ${ }^{1 *}$, Yohana Sutiknyawati Kusuma Dewi ${ }^{1}$, Ferry Hadari ${ }^{2}$ \\ ${ }^{l}$ Jurusan Budidaya Pertanian Prodi Ilmu dan Teknologi Pangan Universitas Tanjungpura, Pontianak \\ ${ }^{2}$ Fakultas Teknik Universitas Tanjungpura, Pontianak \\ Jl. Prof. Dr. H. Hadari Nawawi, 78124 \\ Penulis Korespodensi : oke.anandika@gmail.com
}

\begin{abstract}
Abstrak
Terusan merupakan wilayah pesisir kecamatan Mempawah Hilir, Mempawah Kalimantan Barat. Bidang perikanan merupakan sektor unggulan di Mempawah, terutama budidaya dengan sistem keramba jaring apung (KJA). Tingginya produksi atau hasil ikan ternyata tidak menjamin dapat mengatasi masalah stunting.Permasalahan yang ditemukan adalah rendahnya tingkat kesukaan konsumsi ikan karena cara pengolahan yang tidak praktis sehingga penyediaan di tingkat rumah tangga rendah dan kurang disukai anak karena terdapat duri pada ikan sehingga merasa sulit untuk dikonsumsi. Solusi dari masalah tersebut adalah memberikan teknik pengolahan pangan setengah jadi yaitu menjadi nugget dan kornet ikan dengan diperkaya rempah lokal. Solusi tersebut dapat memecahkan masalah mitra 1 yang merupakan kelompok KJA untuk meningkatkan nilai ekonomi ikan ketika harga ikan rendah, sekaligus permasalahan mitra 2 yang merupakan kelompok PKK Terusan untuk meningatkan penyediaan pangan berbahan baku ikan di tingkat rumah tangga. Kegiatan menunjukan keberhasilan yang ditunjukkan dengan terdapat $60 \%$ dari mitra 1 berhasil mengembangan produk olahan yang telah diberikan dan 50\% dari yang mengembangkan telah menjadikannya sebagai sumber pendapatan tambahan dengan dijual, sedangkan 100\% dari mitra 2 telah mengaplikasikan produk olahan sebagai hidangan di tingkat rumah tangga. Pengolahan ikan menjadi produk setengah jadi dapat meningkatkan kepraktisan dalam pengolahan selanjutnya dan umur simpan yang lebih panjang dengan cara pembekuan sehingga dapat menjadi alternatif untuk meningkatkan konsumsi ikan terutama di tingkat rumah tangga. Harapan yang lebih besar dengan pengolahan ikan menjadi produk setengah jadi dapat meningkatkan minat konsumsi ikan terutama bagi anak hingga dapat menurunkan angka stunting dan meningkatkan angka kecukupan protein (AKP).
\end{abstract}

Kata kunci: KJA, Kornet, Nila, Nugget, PKK

\section{Pendahuluan}

Kecamatan Mempawah Hilir termasuk dalam kabupaten Mempawah dengan luas wilayah $133,48 \mathrm{Km}^{2}$, kecamatan ini terdiri dari 3 kelurahan dan 5 desa yang terbagi menjadi 39 dusun, 69 RW dan 174 RT. Salah satunnya adalah Terusan yang memiliki luas area $7,5 \mathrm{Km} 2$ atau $5,62 \%$ dari luas kecamatan Mempawah Hilir. Terusan terdiri dari 5 dusun, 17 RW, dan 41 RT yang merupakan jumlah terbanyak dibandingkan desa lainnya.

Terusan termasuk wilayah yang berada di pusat kota yang ditandai dengan paling dekatnya jarak kantor camat $(0 \mathrm{Km})$ dan kantor bupati $(0,4 \mathrm{Km})$ dibandingkan dengan desa lainnya yang termasuk dalam Kecamatan Mempawah Hilir. Karakteristik wilayah tersebut menyebabkan
Terusan memiliki jumlah penduduk terbanyak yaitu 11425 jiwa dengan kepadatan penduduk 1523 per $\mathrm{Km}^{2}$. Selain itu Terusan terdata memiliki jumlah penduduk pendatang yang tertinggi yaitu 40 jiwa (BPS, 2017).

Peran sub sektor perikanan di Kecamatan Mempawah Hilir cukup tinggi sebagai penyedia konsumsi protein hewani. Produksi perikanan terus meningkat di Kecamatan Mempawah Hilir menurut BPS (2017) pada tahun 2016 sebesar 10,37\%, yaitu dari 1,61 ribu Ton menjadi 1,78 ribu Ton. Rincian produksi perikanan tersebut dari yang tertinggi hingga terendah adalah 1,038 ribu Ton perikanan laut, 0,7 ribu Ton perikanan budidaya, dan 44 Ton perikanan umum. Akan tetapi tingginya hasil ikan tidak membuat daerah ini terlepas dari masalah 
stunting yang merupakan salah satu masalah kesehatan di Kalimantan Barat. Menurut Riskesdas tahun 2013 prevalensi stunting masih diatas ratarata nasional yaitu $38,6 \%$.

Khusus di Terusan dari hasil wawancara dengan perangkat pemerintah daerah Terusan produksi utama perikanan terdapat pada perikanan budidaya dengan sisten keramba jala apung (KJA). Kelompok pembudidaya ikan KJA sebagai mitra 1 dalam kegiatan pengabdian kepada masyarakat ini adalah kelompok usaha bersama. Kelompok tersebut terdiri dari 10 anggota dengan 10-40 KJA untuk masing-masing anggota. Permasalahan utama kelompok ini adalah harga ikan yang tidak stabil, sehingga pada musim panen harga ikan akan sangat rendah.

Mitra kedua adalah ibu-ibu PKK Terusan. Pemilihan mitra PKK yang merupakan organisasi nirlaba terkait dengan peran ibu rumah tangga dalam menyukseskan program pemerintah adalah besar seperti ketahanan pangan. Pada saat panen raya maka ikan sangat banyak dan harganya jatuh maka perlu inovasi teknologi untuk meningkatkan nilai tambah produk sekaligus dapat menjadi alternatif untuk menambah penghasilan keluarga. Target lainnya adalah meningkatkan konsumsi protein terutama pada anak dengan cara mengolah ikan menjadi lebih menarik dan olahan setangah jadi yang lebih praktis dengan menggunakan bahan lokal berupa bumbu alami sebagai pengganti MSG (Monosodium Glutamat).

Pilihan teknologi diversifikasi olahan berbasis ikan untuk didiseminasikan adalah olahan kornet dan nugget. Pertimbangannya produk tersebut disukai masyarakat terutama untuk lauk tetapi juga dapat digunakan menjadi usaha rumah tangga yang menjanjikan. Namun demikian teknologi yang dikembangkan adalah olahan tersebut dengan meanfaatkan rempah-remapah alam secara alami berada di hutan-hutan di Mempawah. Tujuan pemanfaatan ini adalah melestarikan tanaman indogenus yang berperan sebagai rempah dan saat ini banyak yang ditebang karena digantikan tanaman industri. Salah satu jenis rempah yang akan digunakan adalah daun san-sakng. Menurut Mayasari (2016), daun sansakng segar mengandung asam amino glutamat bebas yang cukup tinggi yaitu $40,44 \mathrm{mg} / \mathrm{g}$. Kandungan tersebut dapat digunakan untuk menggantikan penggunaan Monosodium glutamat (MSG) yang umum digunakan oleh masyarakat dalam bentum micin. Penggunaan daun san-sakng tersebut juga dapat menurunkan penggunaan garam dalam masakan. Menurut Jinap, dkk (2010), penggunaan glutamat pada masakan dapat menurunkan penggunaan $\mathrm{NaCl} 30 \%$ hingga $40 \%$ tanpa mengurangi rasa lezat. Pembuktian pun terlihat menurut Mayasari dkk (2016) bahwa penggunaan bumbu dengan daun san-sang yang ditambahkan garam $0,6 \%$ lebih disukai dibandingkan penambahan garam yang lebih tinggi yaitu $0,8 \%$. Sisi positif lainnya dengan pengurangan penggunaan garam dapat menurunkan potensi penyakit hipertensi, seperti diketahui bahwa penggunaan garam dapat berakibat meningkatkan tekanan darah (hipertensi). Rempah daun sindu memberikan rasa bawang (Scorodocarpus borneensis) dan saat ini telah dapat disediakan dalam bentuk instan (Dewi, dan Mayasari, 2017).

Tujuan dari kegiatan ini adalah adanya inisiasi sebagai penjual produk olahan pada kelompok budidaya ikan KJA dan penerapan produk nugget serta kornet di tingkat rumah tangga.

\section{Bahan dan Metode}

Bahan utama yang digunakan dalam kegiatan ini adalah ikan nila, tapioka, telur, daun san-sakng, dan daun sindu.

Metode yang digunakan adalah dengan sosialisasi, demonstrasi, pelatihan, serta evaluasi dan monitoring. Pengolahan produk ikan menjadi nugget dan kornet menerapkan hasil penelitian yaitu penggunaan daun san-sakng dan sindu sebesar $0,6 \%$.

\section{Hasil dan Pembahasan}

Kegiatan pertama yang dilakukan adalah dengan melakukan sosialisasi (Gambar 1). Kegiatan tersebut berisikan pemberian materi terkait pengolahan ikan menjadi setengah jadi dengan rempah alami sebagai pengganti MSG yaitu daun san-sakng dan daun sindu.

Kegiatan sosialisasi juga dibarengi dengan pemberian kuisioner terkait konsumsi ikan. Kuisioner tersebut bertujuan untuk memperoleh data tingkan kesukaan dan frekuensi konsumsi ikan oleh peserta yang terdiri dari kelompok budidaya ikan KJA dan ibu-ibu PKK Terusan. Data tersebut digunakan sebagai data awal dalam memperoleh informasi sebelum dilakukannya kegiatan. 


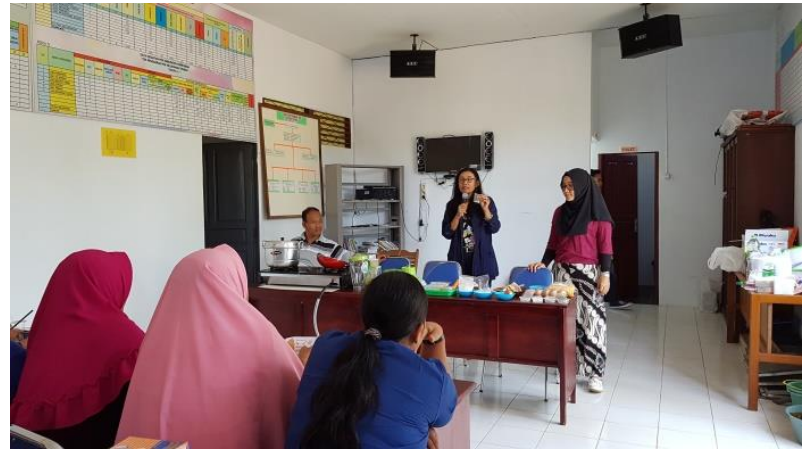

Gambar 1. Kegiatan sosialisasi

Peserta kegiatan secara umum mengkonsumsi ikan sebanyak 4 kali dalam 1 minggu (Gambar 2). Akan tetapi pengungkapan peserta bahwa dalam kelurga anak-anak yang cenderung tidak menyukai konsumsi ikan terutama pada kondisi utuh. Berdasarkan hal tersebut maka kegiatan pengolahan ikan setengah jadi menjadi nugget dan kornet sangat bermanfaat untuk meningkatkan minat dalam mengkonsumsi ikan terutama pada anak-anak. Kesesuaian seperti hasil penelitian yang munjukkan faktor usia sangat menentukan tingkat kesukaan terhadap ikan, yaitu pola konsumsi ikan meningkat seiring dengan meningkatnya usia (Sokib dkk., 2012).

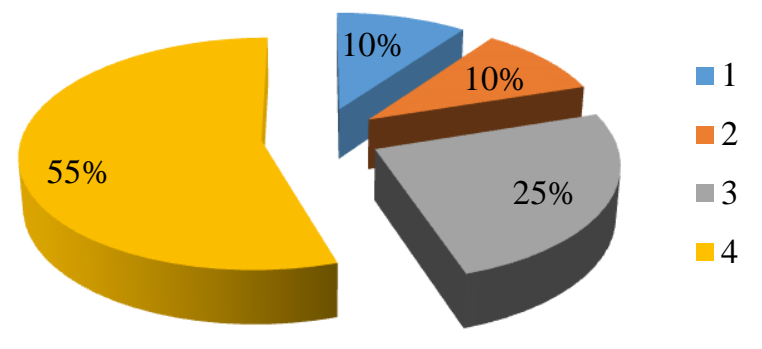

Gambar 2. Frekuensi konsumsi ikan dalam satu minggu

Kegiatan kedua yang dilakukan adalah demonstrasi dan pelatihan. Pelatihan yang dilakukan diawali dengan melakukan demonstrasi pengolahan nugget dan kornet dari ikan nila hingga pengemasan produk (Gambar 3). Pengolahan diawali dengan melakukan pemisahan daging dengan tulang dan duru dari ikan. Daging ikan kemudian dicampurkan dengan bumbu dan ditambahkan sebanyak $0,6 \%$ daun san-sakng dan daun sindu sebagai pengganti MSG dan bawang putih.

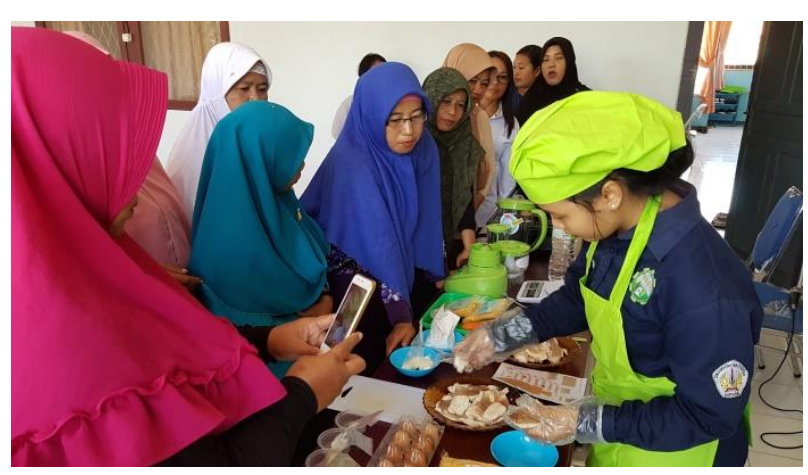

Gambar 3. Demonstrasi olahan ikan

Pelatihan dilakukan dengan cara perwakilan peserta mengulang kembali proses pengolahan ikan yang telah di demonstrasikan (Gambar 4). Hasil peraktek peserta menunjukkan bahwa peserta dapat mengulang kembali proses pengolahan yang telah didemonstrasikan. Hal tersebut dikarenakan 95\% peserta merupakan ibu-ibu yang memang biasa menyediakan makanan di tingkat rumah tangga.

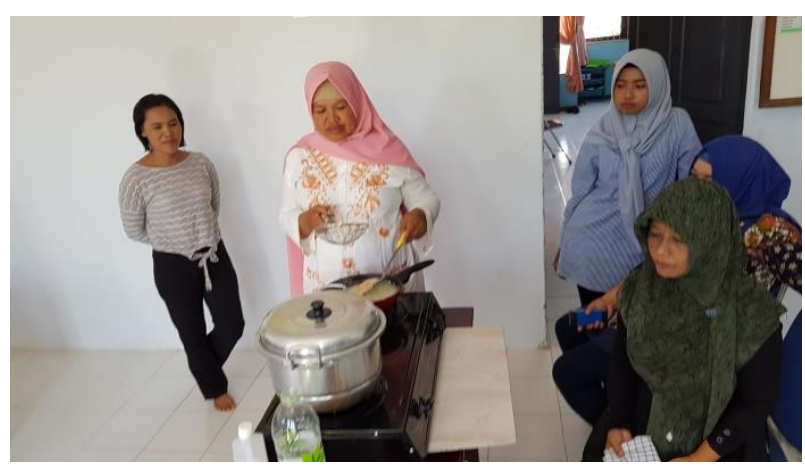

Gambar 4. Pelatihan pengolahan ikan

Tingkat keberhasilan pelatihan dapat ditunjukkan dengan Gambar 5. Gambaran tersebut memperlihatkan tingkat pemahaman peserta dengan $55 \%$ pada tingkat sangat faham dan $45 \%$ pada tingkat faham. Hal tersebut diduga karena penggunaan panduan (ringkasan materi) dalam bentuk brosur dalam kegiatan pelatihan dapat membantu tingkat pemahaman dengan sebagai pengingat ketika lupa terhadap materi yang diberikan. Kesesuaian dengan hasil penelitian yang menunjukkan bahwa adanya panduan yang diberikan kepada peserta pelatihan dapat meningkatkan pemahaman materi kepada peserta (Atmaja, 2014). 


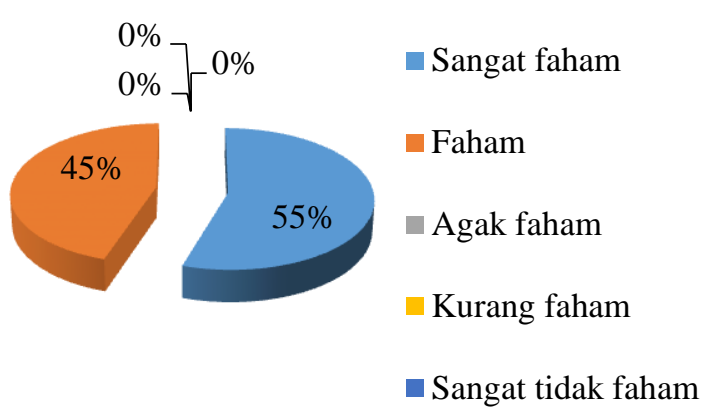

Gambar 5. Tingkat pemahaman peserta pada kegiatan pelatihan olahan ikan

Produk yang dihasilkan dari kegiatan pelatihan adalah berupa olahan ikan menjadi nugget dan kornet dengan kemasan plastik HDPE (High Density Polyethylene) untuk nugget dan kemasan wadah plastik PP (Polypropylene) yang bertuliskan angka 5 dalam segitiga. Penggunaan HDPE pada nugget bertujuan agar plastik tidak rapuh karena penyimpanan beku. Penggunaan PP (logo 5 dalam segitiga) pada kornet dikarenakan wadah tersebut tahan terhadap panas, karena pada pembuatan kornet dilakukan proses pemanasan dengan menggunakan wadah sebagai salah satu tujuan pengawetan.

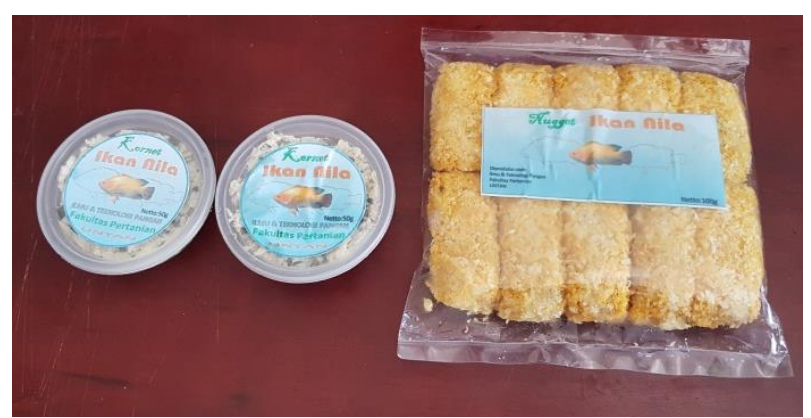

Gambar 6. Produk yang dihasilkan pada kegiatan pelatihan yaitu kornet (kiri) dan nugget (kanan)

Kegiatan keempat merupakan evaluasi dan monitoring. Kegiatan ini dilakukan untuk mengetahui tingkat penerapan materi pelatihan yang telah dilakukan dalam mengolah nugget dan kornet ikan. Hasil menunjukkan bahwa 60\% dari peserta dapat membuat kembali produk olahannya dirumah. Produk olahan yang dihasilkan ditampilkan pada Gambar 7. Peserta juga melakukan pengembangan resep yang telah diberikan, diantaranya adalah menggunakan bahan baku ikan selain ikan nila, menambahkan bumbu alami khas Kalimantan Barat daun kesum, dan mengembangkan produk cemilan dari ikan yaitu stik ikan.

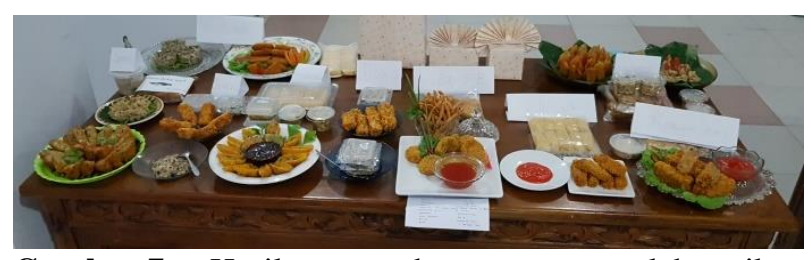

Gambar 7. Hasil pengembangan resep olahan ikan oleh peserta

Nilai tambah dari sisi ekonomi pun telah ditunjukan dari $50 \%$ peserta yang mengembangkan resep yaitu dengan menjadikan produk olahan ikan yang diajarkan sebagai pendapatan tambahan dengan cara menjual produk tersebut. Hasil lainnya adalah seluruh peserta (100\%) telah menerapkan olahan ikan yang diberikan di tingkat rumah tangga dengan tingkat kesukaan didominasi oleh produk nugget (Gambar 8). Hal tersebut diduga disebabkan penampakan pada nugget lebih baik dibandingkan kornet, akan tetapi saran penyajian pada produk kornet untuk meningkatkan kesukaan adalah dengan diaplikasikan pada pembuatan nasi goreng. Nugget menurut Sokib dkk (2012), merupakan salah satu pengembangan produk olahan ikan yang tepat untuk meningkatkan minat konsumsi ikan.

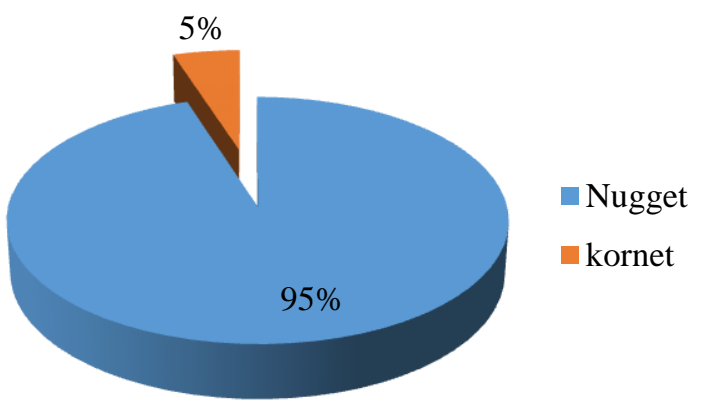

Gambar 8. Tingkat kesukaan produk olahan ikan nugget dan kornet di tingkat keluarga. 


\section{Kesimpulan dan Saran}

Pengolahan ikan menjadi pangan setengah jadi yaitu nugget dan kornet pada kelompok Budidaya Ikan KJA dan ibu-ibu PKK Terusan dapat memberikan nilai tambah dari sisi ekonomi sebagai pendapatan tambahan. Kelompok budidaya ikan KJA 50\% dari anggotanya telah mendapatkan pendapatan tambahan dengan menjual produk nugget ikan. Produk olahan ikan menjadi nugget dan kornet telah diterapkan ditingkat keluarga oleh $100 \%$ peserta dengan jenis produk favorit adalah nugget. Peningkatan konsumsi ikan di tingkat rumah tangga diharapkan dapat menurunkan angka stunting dan meningkatkan Angka Kecukupan Protein (AKP)

Saran yang dapat diberikan adalah penerapan produk kornet untuk diaplikasikan sebagai bahan baku pangan seperti nasi goreng.

\section{Ucapan Terima Kasih}

Ucapan terimakasih kepada Direktur Riset dan Pengabdian Masyarakat Direktorat Jenderal Penguatan Riset dan Pengembangan Kementerian Riset, Teknologi, dan Pendidikan Tinggi yang telah mendanai kegiatan ini melalui Program Prototipe Teknologi untuk Masyarakat dengan nomor perjanjian 151/SP2H/PPM/DRPM/2018. Ucapan terima kasih juga diberikan kepada ibu Katharine Angela Oendoen beserta tim yang telah mendukung keberlangsungannya kegiatan ini.

\section{Daftar Pustaka}

Atmaja, T.T. 2014. Upaya Peningkatan Perencanaan Karir Siswa Melalui Bimbingan Karir dengan Penggunaan Media Modul. Psikopedagogia. 3(2):58-68.

BPS. 2017. Kecamatan Mempawah Hilir dalam Angka 2017. Badan Pusat Statistik Kabupaten Pontianak. Pontianak.

Dewi, Y.S.K., dan Mayasari, E. 2017. Potensi Ekstrak Daun Sindu (Scorodocarpus borneensis Becc.) sebagai Antioksidan Alami Endogenous Borneo. Prosiding Seminar PATPI 2017. Lampung.

Jinap, S., A. R. Ilya-Nur, S.C. Tang, P. Hajeb, K. Shahrim, M.Khairunnisak. 2010. Sensory Attributes of Dishes Containing Shrimp Paste With Different Concentrations of Glutamate and 5-Nucleotides. Journal of Appetite 55. P 239.

Mayasari, E. 2016. Pengaruh Variasi Suhu Kyuring terhadap Komposisi Asam Glutamat Bebas pada Daun Sokai (Albertisia Papuana Becc). Prosiding Seminar Nasional Hasil Riset Baristand Industri Pontianak 2016. 72-78.

Mayasari, E., Lestari, O. A., Saloko, S., dan Ulfa, M. 2016. Karakteristik Sensori Ekstrak Daun San-Sakng (Albertisa Papuana Becc) dengan Penambahan $\mathrm{NaCl}$ di berbagai Konsentrasi pada Panelis Semi Terlatih. Jurnal Ilmiah Teknosains. 3(1):27-33).

Sokib, N., Palupi, N.S., dan Suharjo, B. 2012. Strategi Peningkatan Konsumsi Ikan di Kota Depok, Jawa Barat. Manajemen IKM. 7(2):166-171.

Riskesdas. 2013. Riset Kesehatan Dasar. Badan Penelitian dan Pengembangan Kesehatan Kementerian Kesehatan RI. Jakarta. 